\title{
MOTIVES OF PROSPECTIVE STUDENTS' RESOLVE TO STUDY AT THE HIGHER EDUCATION INSTITUTION
}

\author{
Remigijus Bubnys
}

Tatjana Bakanovienè

Lina Bivainienè

Šiauliai University, Lithuania

\begin{abstract}
In today's world, the choice of a profession and professional career planning are becoming very important processes in young persons' life, during which they make a decision, influencing their future. The first real encounter with the problem of the career choice takes place at school, when a student has to choose study subjects or an educational profile. Later, future students analyse what study programme or higher education institution to choose. There are numerous reasons and factors determining graduates' choice. The aim of the conducted study is to disclose prospective students' motives, choosing the study programme and the higher education institution (in this case, Siauliai University in Lithuania). The applied research method is an online survey, using a semi-structured questionnaire. Research results also disclose the quality of providing information about studying possibilities.

According to the research results, prospective students clearly knew in which higher education institution they would study and what specific programme they would choose. The main source of information choosing studies was information provided on the website of the institution; friends' recommendations were also relevant. Choosing a particular higher education institution, the main motives were personal and the ones directly related to the higher education institution: the wish to study close to home, urban infrastructure, the learning environment and teachers. The choice of a concrete study programme was determined by early career dreams, attractiveness and interest of the study programme as well as employment opportunities.
\end{abstract}

Keywords: choosing the study programme and the higher education institution, motives to study, Šauliai University.

\section{Introduction}

Current changes in the demographics of Lithuania are increasingly forcing the higher education institutions to search for new ways of attracting the students. Within the past decade this process has acquired some features of 
marketing strategy: when the target market and its main segments are clearly identified, and the ways and tools of communication for marketing are chosen.

Higher education institutions have to analyse and evaluate the process annually by identifying the main motives for choosing to study, ways of communication and its tools. Recently the status of a student as a recipient of a service has settled down (Starkute et al., 2013), therefore, the activity of higher education institutions is organized in accordance with the principles of "university of services", "entrepreneur university", which require new patterns of service provision, where the learners as recipients of a service ,want to acquire certain education" (Mikalauskas, Švagždienè, 2008). As a university performs other multi-functions - preparing the citizens for professional, industrial and social activity, passing the knowledge to future generations, assuring intellectual, moral, spiritual, economic development of the society and a personality (Mikalauskas, Švagždienè, 2008) - it is equally important to assure the satisfaction of the needs of a student as a client. The opinion of the latter becomes very important to universities in various aspects: in terms of both the quality of the services provided, and the matters of choosing the higher education institution. Therefore, it is important to distinguish the motives which are related with the choice of profession. Every activity and its success depend on the motive. Researchers note that it is important to know the motives, so that they could be controlled, managed, because the purposefulness of an activity, communication, and its intensity can be changed by changing the motives (Abramauskienè, Kirliauskienè, 2014).

Research subject: the motives of the prospect students for choosing the study programme and the higher education institution.

Research aim: to reveal the motives of the prospect students for choosing a study programme and the higher education institution (Šiauliai University in Lithuania in this particular case) as well as their opinion on the means of information about the studies offered.

\section{Research methodology}

\section{Research method}

A questionnaire-based survey was used for the research. The questionnaire was comprised of 14 questions, 3 from which were socio-demographic: 5 - to reveal the motives for choosing the study programme and the higher education institution, and 6 - to evaluate the information about the study programmes and the higher education institution. 


\section{The research procedure}

The research was conducted in October-November 2016. The participants of the survey were provided with an e-form with the aims of the research and the instructions for filling in the questionnaire.

After the survey, in order to ensure the quality of research, the primary evaluation of data was performed, which allowed to reject the forms filled in incorrectly or not completely and to provide a quality material for data analysis.

Data of quantitative research were analysed using SPSS 16.0 (Statistical Package for the Social Sciences), the methods of descriptive analysis were used: the tables of frequency were drawn. Non-parametrical criteria were applied (Kolmogorov-Smirnov Z, Mann-Whitney) to evaluate the differences for statistical significance (the difference is considered to be statistically significant when the meaning of significance level $\alpha \mathrm{p}$ is $<0,05)$.

\section{Characteristics of the study sample}

The survey involved students of the first and the second cycle, who have chosen to study at Šiauliai University. Representativeness and reliability of the survey's sample is one of the main factors defining the quality of the results (Bitinas, 2013). In author's opinion, complicated calculations for defining the sample are relevant, when the "researcher undertakes to foresee the implementation of the investigated feature, based on the data on a one-off survey", however, the aim of the described survey is more of a declarative nature, therefore, for its results it is more significant, if the sample of the survey includes all groups of members from a population known in advance (in our case these are the first year students of all study programmes of all cycles (Bachelor and Master). The principle of a layered sample composition was chosen: the subjects of survey were divided into "layers", proportional to groups in the population. The respondents of each layer were further selected using the method of simple probability or systematic sampling (Vobolevičius V., 2015).

The survey involved 205 respondents (total number of enrolled students 490). When organising the survey, the following principles of scientific survey ethics were observed: goodwill, free will, and anonymization of survey participants.

Demographic characteristics of the respondents: the distribution of age was as follows: from 18 to 20 years made 36.36 percent., from 21 to 24 years made 33.84 percent, from 25 to 30 years made 13.13 percent., from 31 to 35 years made 8.08 percent, more than 36 years made 8.59 percent. Among the respondents, Bachelor students made 53.03 percent, while Master students made 46.97 percent.

Distribution by the form of studies was as follows: full-time students made 80.90 percent of respondents, part-time students made 10.55 percent, distance 
learning students made 7.04 percent. According to the source of funding, 47.98 percent of respondents were funded by the state, 42.42 percent of respondents were not funded and 7.58 percent received targeted funding.

\section{Results and interpretation}

The process of choosing the studies is complicated, influenced by the complex of psychological, social, economic factors and reasons: some students cannot choose the study programme of their dreams because of scarce economic resources of the family, others are limited by social adaptation problems (failure to adapt, for instance, fear of changing the environment, strangers, etc.), etc. During the studies the self-evaluation of the entrants develops and starts to show, which can affect the motivation to study and to plan a career in a chosen field. Addison R. et al. (2016), in his research on the students' choice to study and motivation for studies and practical activity, points out that at the time of making a choice they are highly motivated, however, later some tendencies show the decrease in motivation for studies and practical activity. Marinas et al. (2014), on the basis of the results of a pilot survey, indicates that the professional decision is more influenced by pragmatic motives (socio-economic status of the family, environment of the higher education institution, etc.), rather than emotional motives (experience of relatives, friends, their recommendations, etc.). The results of this and similar surveys show that the motivation of students is changing, especially at the beginning of their studies, the initial motives and attitudes of the student change in regard to their choice. Therefore, the survey aimed at trying to determine, what were the main motives having encouraged the prospect students to choose the study programmes and the higher education institution. The results are shown in tables 1 and 2 .

Table 1 Motives for choosing the higher education institution

\begin{tabular}{|l|c|c|}
\hline Motives & N & Percent \\
\hline Failed to enter a different school & 15 & 7.58 \\
\hline Were directed / recommended by their parents* & 43 & 21.72 \\
\hline Teachers recommended & 45 & 22.73 \\
\hline A friend came to study here & 59 & 29.8 \\
\hline University is positively described in the public sphere & 69 & 34.85 \\
\hline $\begin{array}{l}\text { This higher education institution is the only one to have the speciality } \\
\text { of my dreams }\end{array}$ & 72 & 36.36 \\
\hline My relatives studied in this city (parents, siblings, etc.) & 84 & 42.42 \\
\hline I liked the lecturers (if you have met them) & 101 & 51.01 \\
\hline I liked the environment of studies (if you have visited the university) & 111 & 56.06 \\
\hline I liked the city & 120 & 60.61 \\
\hline I wanted to study closer to my home & 149 & 75.25 \\
\hline
\end{tabular}

* Statistically significant difference has been found 
When evaluating the motives for choosing the higher education institution, it should be noted that one of the main motives for choosing the higher education institution is geographical location, which reflects the attractiveness of both the city and the region, as well as the significance of the distance from home (safety is important to young people - home is close, the parents can help). Another important group of motives is the attractiveness of the University (both its environment and the community) and the experience of other people significant to the student at this higher education institution. More than 36 percent of respondents indicted than they have chosen this higher education institution because of the uniqueness of studies. More than one fifth indicated that their choice had been influenced by the recommendations of other people. Similar results, the prevalence of pragmatic motives, are described by Martinas et al. (2014), Voitkāne et al. (2006) in research.

When analysing the motives for choosing the higher education institution in the aspect of a cycle, a statistically significant difference has been noticed when evaluating the group of motives influenced by other people's experience and recommendations $(p=0.022)$. To Bachelor students the opinion and recommendations of parents were especially significant when choosing a higher education institution.

Table 2 Motives for choosing a study programme

\begin{tabular}{|l|r|r|}
\hline \multicolumn{1}{|c|}{ Motives } & N & \multicolumn{1}{|c|}{ Percent } \\
\hline Failed to enter the desirable study programme* $(0,006)$ & 19 & 9.6 \\
\hline $\begin{array}{l}\text { My relatives (parents, siblings, etc.) studied in this study } \\
\text { programme* }(0,003)\end{array}$ & 27 & 13.64 \\
\hline Affordable tuition fee & 44 & 22.22 \\
\hline Teachers recommended & 44 & 22.22 \\
\hline Prestigious study programme & 52 & 26.26 \\
\hline Specialists of this field receive large wages* $(0,016)$ & 57 & 28.79 \\
\hline I liked the lecturers (if you have met them) $(0,021)$ & 90 & 45.45 \\
\hline $\begin{array}{l}\text { I liked the environment of studies (if you have visited the } \\
\text { university) }\end{array}$ & 102 & 51.51 \\
\hline Good employment possibilities* (0,024) & 107 & 54.04 \\
\hline This is the speciality of my dreams & 107 & 54.04 \\
\hline Interesting and promising study programme & 147 & 74.24 \\
\hline
\end{tabular}

* Statistically significant difference has been found

When evaluating the motives for choosing the study programme, some of the most significant ones were the uniqueness of the study programme, its perspectives, meeting the interests of the entrant and the employment possibilities in this field. The motives related with University's attractiveness were also considered to be significant. More than one fourth of the respondents 
considered the prestige of the study programme, tuition fee and recommendations by the teachers to be significant.

When analysing the motives for choosing the higher education institution in the aspect of the cycle, a statistically significant difference has been found when evaluating the experience of people significant to the student in this study programme. $(p=0.003)$. Bachelor students find the experience of their relatives and their recommendations more significant. Also, the latter, when choosing the studies, consider the employment possibilities $(\mathrm{p}=0.02)$ and the salary of chosen specialists $(p=0.016)$ to be more significant motives. Master students indicated University lecturers, who could have influenced their decision to continue their studies, as a significant motive $(\mathrm{p}=0.003)$.

When applying to a university the entrants can submit 9 requests, which are rated in decreasing order by priority. According to this, the higher education institutions and study programmes listed as their number one priority are considered to be the most attractive ones among the entrants. The respondents who listed their chosen higher education institution as their number one priority make 90.9 percent, while the study programme was listed by 83.3 percent of respondents.

Table 3 Sources of information about the study programmes and the higher education institution

\begin{tabular}{|l|c|c|}
\hline \multicolumn{1}{|c|}{ Sources of information } & N & Percent \\
\hline During the excursions to the university & 8 & 4.04 \\
\hline In news forums, via e-mail, etc. & 12 & 6.06 \\
\hline During events (competitions, public lectures, etc.) & 14 & 7.07 \\
\hline At the studies fair (Litexpo, etc.) & 18 & 9.09 \\
\hline During the career days at the university/ school & 23 & 11.62 \\
\hline In press, specialized magazines (Atrask, Kur stoti?, Veidas, etc.) & 26 & 13.13 \\
\hline In social networks & 49 & 24.75 \\
\hline Recommendations by the relatives (parents, siblings, etc.) & 54 & 27.27 \\
\hline Recommendations by friends & 55 & 27.78 \\
\hline On the website of the University www.su.lt & 136 & 68.69 \\
\hline
\end{tabular}

Such attribution of priority encouraged us to find out what factors influenced this decision. More than one half of the respondents indicated that their choice has been influenced by their decision of the higher education institution made in advance. It allows us to make an assumption that the marketing of the higher education institution related with the development of image in society is significant, because the entrants find it important in the process of choosing to find enough information about both the higher education institution and the study programme, and the demand of the profession in labour 
market. It should be noted that more than 40 percent of respondents indicated that their decision to choose the studies in this higher education institution has not been planned in advance, but rather influenced by accidental factors, such as the exam results, failure to enter a different higher education institution.

The research aimed to find out the evaluation of the process of student information about the higher education institution and the study programmes. These questions have revealed their satisfaction by the quality of information contents, the accessibility of information sources and their usefulness.

When analysing the results of the survey, it has been noticed that, in the respondents' opinion, the official website of the higher education institution is a useful source of information in terms of both the study programme and the University. Almost a third of the respondents indicated that an important source of information to them was the experience of their relatives and their recommendations. Information events organized to the prospect students meet the expectations and the need for information about the studies of only a part of the respondents. In this context, a typical modern student was revealed to be the representative of the millennium generation (they make more than a third in the survey), who tend to read the information using a method of a "loop" (Targamadzè, 2014) - ,reading not a sentence by sentence but on the basis of site opening principle", therefore, it is likely that this was the reason why the information given on the website was considered to be the most significant source.

\section{Conclusions}

1. The choice of a higher education institution and a particular speciality is determined by two main factors: external necessity, i.e. requirements raised by the environment and the internal motivation of the person itself, their self-determination, consciousness in purposefully choosing their profession and in planning it.

2. When choosing the higher education institution, the main motives were personal, directly related with the school: a wish to study not far from home, infrastructure of the city, studying environment and the lecturers. A choice of a particular programme was influenced by a preconceived desire to choose this particular field, attractiveness and the interest of a programme, and the employment possibilities.

3. The most significant motives of students choosing a study programme were its uniqueness, perspectives, the prestige of the study programme, tuition fee, recommendations of teachers, and employment possibilities. Prospect students were clearly determined in which higher education institution they are going to study and which study programme they are going to choose. 
The main source of information, when choosing the studies, was the information provided on the website of the higher education institution, also among the most relevant ones was the recommendation by friends. Decision to choose studies in this particular higher education institution has not been planned in advance, but rather determined by accidental factors, such as exam results, failure to enter another school.

\section{References}

Bitinas, B. (2013). Rinktiniai edukologiniai raštai. Vilnius: Edukologija.

Marinas, C., Igret, R. S., \& Agoston, S. I. (2014). Students' Career Motivation - a Pilot Study. Proceedings off the 8th International Management Conference „Management Challenges for Sustainable Development", November 6th-7th, 2014, Bucharest, Romania. 973-980 Retrieved from http://conferinta.management.ase.ro/archives/ 2014/pdf/96.pdf

Mikalauskas, R., Švagždienè, B. (2008). Universitetų valdymo problemos žinių visuomenëje: pertvarkos poreikis. Organizacijų vadyba: sisteminiai tyrimai. 2008 (45). 71-81.

Starkutè, J., \& Valinevičienė, G. (2013). Studentas - universiteto klientas ar akademinès bendruomenès narys? Aukštojo mokslo kokybès tyrimai. 2013 (10).

Targemadzè, V. (2014). Z karta: charakteristika ir ugdymo metodologinès linkmès izžvalga. Tiltai. 2014, 4, 95-104. Retrieved from http://193.219.76.12/index.php/tiltai/article/view/952/pdf

Vobolevičius, V. (2015). Statistine duomenu analize. Kaunas: KTU. Retrieved from http://www.lidata.eu/index.php?file=files/mokymai/sda/sda.html\&course_file=sda_turin ys.html

Voitkāne, S., Miezīte, S., Rasčevska, M., \& Vanags, M. (2006). Presentations of Empirical and Theoretical Studies: Student motivation for choice of study program, psychological well-being, perceived social support and needs at the start of university studies. Baltic Journal Of Psychology, 7 (1), 46-59. Retrieved from http://www.lu.lv/fileadmin/user_upload/lu_portal/apgads/PDF/BalticJournPsychol2006-Vol-7_No-1.pdf 